\title{
PT1c Stage Finding
}

National Cancer Institute

\section{Source}

National Cancer Institute. pT1c Stage Finding. NCI Thesaurus. Code C48763.

A pathologic primary tumor TNM stage finding. The definition of PT 1c stage finding depends on the particular type of cancer that it refers to; for example, for breast cancer, PT 1c stage finding is defined as follows: cancer with tumor size more than $1.0 \mathrm{~cm}$, but not more than $2.0 \mathrm{~cm}$ in greatest dimension; for fallopian tube cancer, pT 1c stage finding is defined as follows: cancer with tumor limited to one or both tubes with extension onto or through the tubal serosa, or with malignant cells in ascites or peritoneal washings. (from AJCC 7th Ed.) 